Elier et al - $\mathrm{mGlu}_{5}$ receptors and relapse

\title{
A medium throughput rodent model of relapse from addiction with behavioral and pharmacological specificity
}

William J.A. Eiler II ${ }^{1,2}$, Scott D. Gleason ${ }^{2}$, Jodi L. Smith ${ }^{3}$, and Jeffrey M. Witkin ${ }^{2,4,5}$

${ }^{1}$ Department of Psychology

Franklin College, Franklin Indiana USA

${ }^{2}$ Neuroscience Discovery

Lilly Research Labs, Indianapolis Indiana USA

${ }^{3}$ Laboratory of Antiepileptic Drug Discovery, St. Vincent's Hospital, Indianapolis, Indiana USA

${ }^{4}$ Department of Neurological Surgery

Indiana University School of Medicine, Indianapolis Indiana USA

${ }^{5}$ Department of Chemistry \& Biochemistry

University of Wisconsin-Milwaukee, Milwaukee Wisconsin USA

\section{Correspondence to:}

Jeffrey M. Witkin, Ph.D.

Witkin Consulting Group

Carmel, Indiana 46033 USA

(317) 933-1167

witkinconsult@gmail.com

This is the author's manuscript of the article published in final edited form as:

Eiler, W. J. A., Gleason, S. D., Smith, J. L., \& Witkin, J. M. (2019). A medium throughput rodent model of relapse from addiction with behavioral and pharmacological specificity. Pharmacology Biochemistry and Behavior. 


\section{Document Statistics}

Abstract: 225 words

Tables: 1

Figures: 4

\section{Non-standard Abbreviations}

ABT-431 - diacetyl prodrug form of (5 a R, 11 b S)-4,5,5a,6,7,11b-hexahydro-2 propyl-3thia-5-azacyclopent-1-ena[c]-phenanthrene-9,10-diol (A-86929)

FR1 - fixed-ratio 1

LY379268 - (1R,4R,5S,6R)-4-Amino-2-oxabicyclo[3.1.0]hexane-4,6-dicarboxylic acid MPEP - 2-Methyl-6-(phenylethynyl)pyridine MTEP - 3-((2-Methyl-4-thiazolyl)ethynyl)pyridine 


\begin{abstract}
One of most formidable problems in the treatment of addiction is the high rate of relapse. The discovery of medicines to help mitigate relapse are aided by animal models that currently involve weeks of training and require surgical preparations and drug delivery devices. The present set of experiments was initiated to investigate a rapid 8day screening method that utilizes food instead of intravenous drug administration. Male Sprague-Dawley rats were trained in a reinstatement paradigm in which every lever press produced a $45 \mathrm{mg}$ food pellet concurrently paired with a light and tone. Behavior was subsequently extinguished with lever responses producing neither food nor foodassociated stimuli. Reinstatement of responding was evaluated under conditions in which the first three responses of every 5 min time bin produced a food pellet along with foodassociated stimuli. The $\mathrm{mGlu}_{5}$ receptor antagonists MPEP and MTEP produced a significant reduction in reinstatement while failing to alter responding where every response produced food. The cannabinoid $\mathrm{CB}_{1}$ receptor antagonist rimonabant and the $\mathrm{mGlu}_{2 / 3}$ receptor agonist LY379268 also selectively reduced reinstatement. Other compounds including clozapine, $d$-amphetamine, chlordiazepoxide, ABT-431, naltrexone and citalopram were without effect. The results suggest that relapse-like behavioral effects can be extended to non-pharmacological reinforcers. Drug effects demonstrated both behavioral and pharmacological specificity. The present experimental design thus allows for efficient and rapid assessment of the effects of drugs that might be useful in the treatment of addiction-associated relapse.
\end{abstract}




\section{INTRODUCTION}

One of most formidable problems in the treatment of addiction is the high rate of relapse following periods of prolonged abstinence (Hunt et al. 1971; O'Brien 1997). In humans, initiation of drug-taking behavior following abstinence is typically preceded by craving for the abused drug. Motivation to re-engage patterns of drug-seeking and drugtaking can be produced by the drug itself or by the presentation of stimuli associated with drug taking behavior (Wikler, 1973; Wikler and Pescor, 1967).

Initial work on the creation of an animal model of human drug relapse began over three decades ago with the seminal work of Stretch and colleagues (1971) and Davis and Smith (1976). Little has changed since the emergence of the paradigm with the basic methodology remaining essentially the same. Animals are first trained to produce responses by reinforcing those responses by drug infusion. Following acquisition of drug-taking, the behavior is extinguished by removal of the drug and drug-associated stimuli. Drug-seeking behavior is then reinstated by the presentation of a reinstatement trigger that can include exposure to the drug itself or drug associated stimuli (Jaffe et al. 1989; Ludwig et al. 1974; O'Brien et al. 1992) or the presence of a stressor (Brown et al. 1995; Sinha, 2001). Each of these factors has been shown to produce self-reports of craving andrelapse in abstinent humans (Childress et al., 1999; Robbins et al., 1999; Walsh et al., 2000; Wasserman et al., 1998).

Animal models of relapse generally use intravenous drugs as reinforcers requiring surgical preparations and drug delivery devices. In addition, these relapse models require long training periods before novel potential anti-craving compounds can be evaluated. For example, Kim et al. (2015) used intravenous cocaine administration requiring surgical implantation of indwelling intravenous catheters followed by recovery time, 12 days of cocaine self-administration training, followed by 9 days of extinction training. In the present set of experiments, we utilize food as a reinforcer in a paradigm that allows anti-relapse drug testing in 8 days. The idea behind this method is the overlap in functional behavioral and biological substrates for reinforced behaviors that transcend the specific reinforcing stimulus (drug or food).

Commonalities in the functional control of behavior by diverse reinforcers have been demonstrated (Kelleher and Morse, 1968; Barrett, 1987; Witkin and Katz, 1990). It is increasingly recognized that the behavioral bases and biological substrates underlying addictions of drug- and non-drug stimuli share common ground (c.f., Chamberlain et al., 2016; Chen et al., 2017; Rogers, 2017; Volkow et al., 2012, 2017). Nonetheless, the generality of relapse phenomenon to non-drug reinforcers has undergone little experimental scrutiny. Studies have shown that stimuli associated with either food reward or pharmacological reinforcers can produce motivation to seek out and to crave these reinforcers (Brody et al., 2002; Childress et al., 1999). Such a motivational state is what is thought to produce relapse not only to drug-taking behavior, but as Berthoud (2004) suggests, relapse to feeding as well. For example, the anxiogenic drug, yohimbine, 
can reinstate behavior following a period of extinction in animals previously trained to self-administer food just as it has after drug reinforcers (Ghitza et al., 2006).

The over-arching goal of the present study was to evaluate the utility of a new animal model of food reinstatement developed from modifications of the classic drugreinstatement paradigms. We first established the reliability of generating reinstatement of extinguished behavior after only 8 days. Next, we determined the relative efficacy of different conditions to induce reinstatement of behavior. Subsequently, several drugs were tested under these conditions to assess their ability to dampen reinstated behavior. The drugs selected were based upon those used in patients and those suggested to be anticraving drugs in the preclinical scientific literature. These drug effects were compared to effects of other compounds that are generally not thought of as anti-craving medications. Thus, these pharmacological studies begin to ascertain 1) whether the 8-day model has predictive validity for detecting anti-relapse drugs and rejecting drugs that are not applicable for anti-relapse therapeutics, and 2) whether a food-based reinstatement model detects comparable pharmacological mechanisms to those detected with drug reinforcer-based models. In addition to beginning to define pharmacological specificity in this model, we utilized control behaviors (non-reinstated behaviors) to determine if the drug effects on reinstatement are behaviorally specific. It is argued that drugs that dampen relapse behaviors at doses that do not affect the non-relapse behaviors should be considered as specific pharmacological mechanisms for relapse prevention.

Drugs that have some validation as anti-craving medications selected for investigation are briefly outlined here. The $\mathrm{CB}_{1}$ receptor antagonist rimonabant, that has been used as an anti-obesity drug (Rubio et al., 2007) was predicted to reduce craving (Kirkham, 2008) and has demonstrated reductions in hunger in humans (Koch et al., 2017) and craving in animal models of reinstatement (Cohen et al., 2005; De Vries et al., 2001; Piomelli, 2001; Schindler et al., 2016; Ward et al., 2009). In addition to opioid abuse disorders, naltrexone is used in the treatment of alcohol addiction where it reduces craving in humans (Hendershot et al., 2017) and attenuates reinstatement to some drugs of abuse in animal models (Anggadiredja et al., 2004; Ciccocioppo et al., 2003; Liu and Weiss, 2002).

Dampening of glutamate neurotransmission by $\mathrm{mGlu}_{5}$ receptor antagonism has been suggested as an anti-relapse mechanism from reinstatement studies in rodents (Bäckström et al., 2004; Bespalov et al., 2005; Kim et al., 2015; Knackstedt and Schwendt, 2016; Pomierny-Chamiolo et al., 2017a; Richard, 2019; Tessari et al., 2004). Likewise, reducing glutamate outflow by $\mathrm{mGlu}_{2 / 3}$ receptor agonists has also been shown to be an effective method of reducing reinstated behaviors in rodent models (Baptista et al., 2004; Pomierny-Chamiolo et al., 2017b) or in primates (Justinova et al., 2016). Drugs that are not considered to have anti-craving properties were studied for comparison: the antipsychotic drug clozapine, the psychostimulant, $d$-amphetamine, the anxiolytic drug chlordiazepoxide, the antidepressant citalopram, and the dopamine receptor agonist ABT- 
431. Although some justification is provided for the compounds used for assay validation in the present study, it is recognized that until there are medicines proven for their efficacy against drug abuse relapse and/or food-related behaviors, these tools remain imperfect. The validation of predictive animal models depends upon existing and emerging data gained from controlled studies from both the preclinical and clinical laboratories that reciprocally inform one another (Willner, 1984). 


\section{MATERIALS AND METHODS}

Subjects. Male Sprague-Dawley rats (Harlan Sprague-Dawley, Indianapolis, IN, USA) weighing 275-305 g upon arrival were used for all phases of this study. A total of 475 rats were used in these experiments. These animals were housed individually to allow for food restriction to produce animals weighing $~ 85 \%$ of their free feeding weight. All animals were fed daily. While food was restricted, all animals had free access to water. All animals were placed on a normal light/dark cycle with lights on at 6:00 am and off at 6:00 pm with experiments conducted between 9:00 am and 4:00 pm. Animals were removed from the vivarium in their home cages and transported to the testing room. All experiments were conducted according to the Guidelines for Care and Use of Laboratory Animals under protocols approved by a local animal care and use committee and under monitoring by veterinary staff.

Apparatus. Animals were tested in 14 standard rat operant chambers (Med Associates, Inc, St. Albans, VT, USA) equipped with 2 levers on a single wall with a pellet delivery assembly with the food trough located between the levers (see Alt et al., 2005). Each chamber was also equipped with a house light, as well as white cue lights above each lever and an audio tone generator (sonalert @ $4500 \mathrm{~Hz}$ and $65 \mathrm{~dB}$ ). The grid floor of the chamber enabled delivery of scrambled electric shock.

Drugs and Food Pellets. A number of psychoactive drugs were tested in this study in order to evaluate the dynamics of the new reinstatement paradigm. These drugs include the antipsychotic clozapine, the benzodiazepine anxiolytic chlordiazepoxide, the dopamine $\mathrm{D}_{1}$ receptor agonist ABT-431, the dopamine releaser $d$-amphetamine, the pan opioid receptor antagonist naltrexone, and the selective serotonin reuptake inhibitor citalopram which were purchased from Sigma Chemical Company (St. Louis, MO). We also studied, the cannabinoid $\mathrm{CB}_{1}$ receptor antagonist SR141716A (rimonabant), the $\mathrm{mGlu}_{2 / 3}$ receptor agonist LY379268, and the $\mathrm{mGlu}_{5}$ receptor antagonists MPEP and MTEP which were synthesized at the Lilly Research Labs. All agents were administered via intraperitoneal (i.p.) injection $30 \mathrm{~min}$ before the start of the test session in an injection volume of $1.0 \mathrm{ml} / \mathrm{kg}$. Clozapine, chlordiazepoxide, ABT-431, LY379268, MPEP, MTEP, naltrexone and citalopram were dissolved in sterile water, while rimonabant was dissolved in a suspension of $1 \% \mathrm{CMC}, 0.5 \% \mathrm{SLS}, 0.085 \%$ providone, and $0.05 \%$ antifoam.

The food pellets used in this study were $45 \mathrm{mg}$ dustless precision pellets (\#F0021) manufactured by Bio-Serv products (Frenchtown, NJ, USA).

\section{Reinstatement Paradigm.}


Response Training: Upon arrival, animals were allowed at least three days to habituate to their new environment before testing was begun. Following the habituation period, animals were tested once daily in a $30 \mathrm{~min}$ food self-administration session. Three 45mg food pellets were placed in the food trough prior to the first test session to help animals associate the trough with food delivery. During all training sessions, responses on the right lever delivered one $45 \mathrm{mg}$ food pellet and produced the concurrent presentation of an audible tone and house light illumination both lasting $2 \mathrm{sec}$.

Responses on the right lever were reinforced under a fixed ratio (FR) 1 schedule of reinforcement whereby each lever press produced food. Responding on the left lever produced no reinforcer or associated stimuli. Each session ended when either 50 pellets had been delivered or 30 min elapsed, whichever occurred first. Training continued until all animals earned all 50 food pellets within the $30 \mathrm{~min}$ session for two consecutive sessions. Any animals that failed to meet this criterion within 7 sessions were excluded from the experiment. This value by experiment was relatively low (2.1\%). This phase of the experiment lasted 3 days.

Extinction: The extinction phase began immediately after the subjects had successfully acquired the response training criterion noted above and lasted for 4 consecutive experimental sessions. During extinction, animals were tested daily for a 30 min experimental session during which responses on the right lever did not produce food pellets or the reinforcer-associated stimuli (i.e. tone and house light). As during acquisition, responding on the left lever produced no reinforcer or food-associated stimuli. Animals continued responding under extinction until their responses had stabilized $( \pm 20 \%)$ for three consecutive days.

Reinstatement: Following extinction, food reinstatement was evaluated. In this portion of the experiment, subjects were placed in the operant chamber for a $30 \mathrm{~min}$ experimental session separated into 5 min time bins. During reinstatement, only the first three right lever responses of each $5 \mathrm{~min}$ period were reinforced by a $45 \mathrm{mg}$ pellet and the presentation of the food-associated stimuli. Subsequent responses on the right lever produced only the tone and house light illumination. As before, responses on the left lever were recorded but not reinforced. Reinstatement sessions ended after 100 right lever responses or when $30 \mathrm{~min}$ had elapsed, whichever occurred first.

Second Reinstatement: In order to best utilize experimental animals, all rats were studied under a second reinstatement test. This phase began with the reacquisition of the food self-administration behavior on the day following the initial reinstatement session. During reacquisition, animals were tested once daily using the same parameters as the rraining sessions described above. Animals were tested over 3 to 4 sessions to ensure that all subjects responded to criterion, earning the maximum 50 reinforcers for 3 consecutive sessions. After reacquisition of responding, the rats entered a second set of extinction sessions which continued until responding had stabilized. Following extinction, animals underwent a second reinstatement session identical to the one 
described above. This allowed for the testing of a second drug or drug vehicle using the same animals. No additional tests were conducted on these rats. Thus, in most, but not all experiments, the same rats used for one drug or vehicle test, were used again in one additional experiment. A total of 5-9 rats were used for each experimental data point.

Comparison of Reinstatement Stimuli. A host of stimuli were evaluated to establish the comparative efficacy of these stimuli to reinstate responding after extinction. Following extinction, stimuli that might produce relapse to food-seeking were evaluated the next day (day 8). The following stimuli were studied: response-produced presentations (FR1) of a) food-associated stimuli (tone + light), b) food alone, c) food plus food-associated stimuli, d) food plus food-associated stimuli for the first three responses only, e) foot-shock $(0.1 \mathrm{~mA}$, for $100 \mathrm{msec})$ in the absence of food or foodassociated stimuli, and response-independent food delivery wher food was delivered along with food-associated stimuli every $30 \mathrm{sec}$. Experimental sessions continued for 60 min or 100 presentations of stimuli, whichever occurred first.

Fixed Ratio (Maintenance) Paradigm. In these experiments, rats were maintained under a schedule of response-produced food delivery. Responses were not extinguished or reinstated as in the reinstatement conditions described above. Drug effects under this maintenance condition could then be compared to drug effects under the reinstatement condition to asses the behavioral specificity of drug effects on reinstated behavior.

Food Training: All animals were allowed at least three days to habituate to their new environment after arrival to the vivarium before testing was begun. Animals were then trained under the FR1 schedule of food delivery as described above. Training continued until all animals earned all 100 possible reinforcers within the 30 min test session for two consecutive sessions. Any animals that failed to meet this criterion within 7 sessions were excluded from the experiment. This value by experiment was relatively low $(1.3 \%)$.

Evaluation of Drug Effects: After training, responding was evaluated in these animals following drug administration. Subjects were placed in the operant chamber for $30 \mathrm{~min}$ and each right lever response was reinforced by a $45 \mathrm{mg}$ pellet and the associated stimuli just as in the training sessions above. As before, responses on the left lever were recorded but not reinforced. Each session ended after 100 right lever responses had been made or when 30 min had elapsed, whichever occurred first.

Data Analysis. Data were collected for the mean number of responses. Entry into the food trough was not recorded. A one-way analysis of variance (ANOVA) was performed on dose-effect data for each compound. Two-way ANOVA was used to evaluate data over experimental sessions (treatment $\mathrm{x}$ experimental session). Significant overall ANOVA values were subsequently analyzed by Dunnett's post-hoc test. 


\section{RESULTS}

\section{Reinstatement of Food-Maintained Responding by Food Presentation and/or by Discriminative Stimuli.}

The ability of different stimuli to reinstate responding after extinction was examined and the data are shown in figure 1. Comparing all reinstatement conditions to one another resulted in a significant effect of treatment condition $[F(5,47)=16.4, p$ $<0.0001)$. All stimuli investigated produced reinstatement of responding that was significantly greater than responding on the last day of extinction. The greatest reinstatement was produced by response-produced food and response-produced food with concurrently-delivered food-associated stimuli. All other inducers of reinstatement produced lower and roughly equivalent levels of responding. The reinstatement condition of response-produced food + food-associated stimuli for the first 3 responses was then utilized to evaluate drug effects as reported below.

Figure 2 illustrates responding under the food self-administration paradigm during acquisition, extinction, and reinstatement. All animals successfully acquired the lever press response (right lever) and reached criterion of 50 food deliveries within the 30 min experimental session by day 2 of training. During acquisition, there were no statistical differences across the three groups of $\operatorname{rats}[\mathrm{F}(2,57)=0.63, \mathrm{p}>0.05]$, across experimental sessions $[\mathrm{F}(2,57)=0.16, \mathrm{p}>0.05]$, and no group $\mathrm{x}$ session interaction $[\mathrm{F}(4,57)=0.36, \mathrm{p}>0.05]$.

During extinction, responses on the right lever significantly declined relative to responding during the acquisition period with significant differences compared to the last day of acquisition by extinction day 2. Two-way ANOVA confirmed a significant effect of experimental session on behavior $[\mathrm{F}(3,76)=9.8, \mathrm{p}<0.0001)$. There were no statistically-significant differences in extinction across groups $[\mathrm{F}(2,76)=0.32, \mathrm{p}>0.05]$ and no session $x$ group interaction $[F(6,76)=0.98, p>0.05]$.

Three stimulus configurations were delivered on the day following extinction (day $8)$. There was a significant effect of treatment group on reinstated behavior $[F(2,21)=$ $8.7, \mathrm{p}<0.001)$. In this experiment as with the data in figure 1 , food-paired stimuli alone were sufficient to significantly reinstate extinguished responding (Fig. 2). Responseproduced food delivery alone (first 3 responses of each 5 min time bin) or responseproduced food in the presence of food-associated stimuli produced large increases in responses post extinction. (Fig. 2).

\section{Reinstatement of Food-Maintained Responding following Drug Administration. Table}

1 shows the effect of multiple pharmacological agents on the reinstatement of food selfadministration. Only rimonabant, LY379268, MPEP, and MTEP were effective in altering reinstated responding. Clozapine, $d$-amphetamine, chlordiazepoxide, ABT-431, 
naltrexone, and citalopram all failed to affect the reinstatement of food selfadministration as evaluated by this paradigm.

Along with their effects on reinstatement, each of the compounds was evaluated under a FR1 schedule (response maintenance condition) to determine the behavioral specificity of any effects observed on reinstatement. These data are summarized in Table 1. Under these conditions, only LY379268 and MTEP altered responding under an FR1 schedule of reinforcement (response maintenance) with all other tested compounds failing to affect mean responding.

Effect of the mGlu 5 Receptor Antagonist MTEP on Reinstatement of FoodMaintained Responding: Figure 3 (top panel, black bars) illustrates the effect of MTEP $(3.0-10.0 \mathrm{mg} / \mathrm{kg}$ ) on responding following reinstatement. MTEP significantly suppressed response reinstatement $[\mathrm{F}(3,26)=16.64, \mathrm{p}<.01]$ with 5.6 and $10.0 \mathrm{mg} / \mathrm{kg}$ significantly separating from vehicle control.

MTEP was also studied in rats responding under FR1 schedules of food delivery (response maintenance condition). MTEP did not significantly affect responding under the FR1 schedule (Fig. 3, top panel, checked bars) $[\mathrm{F}(3,26)=2.03, \mathrm{p}>0.05]$.

\section{Effect of the mGlu 5 Receptor Antagonist MPEP on Reinstatement of Food-}

Maintained Responding: Effects of MPEP $(3.0-10.0 \mathrm{mg} / \mathrm{kg})$ on responding following reinstatement is depicted figure 3 (bottom panel, black bars). As with MTEP, the 5.6 and $10.0 \mathrm{mg} / \mathrm{kg}$ doses suppressed reinstatement with the $3.0 \mathrm{mg} / \mathrm{kg}$ failing to effect responding when compared to vehicle $[\mathrm{F}(3,35)=10.99, \mathrm{p}<.01]$.

MPEP did not decrease responding under the response maintenance FR1 schedule $[\mathrm{F}(3,35)=1.39, \mathrm{p}>.05]$ even at doses that suppressed response reinstatement $($ Fig. 3, bottom panel, checkered bars).

\section{Effect of the mGlu $2 / 3$ Receptor Agonist LY379268 on Reinstatement of Food-}

Maintained Responding: LY379268 significantly reduced responding under the reinstatement condition $[\mathrm{F}(3,34)=37.2, \mathrm{p}<.01]$. Post-hoc testing indicated that the 3.0 and $5.6 \mathrm{mg} / \mathrm{kg}$ doses of LY379268 produced significant $(\mathrm{p}<0.01)$ suppression of responding while the $1.0 \mathrm{mg} / \mathrm{kg}$ dose failed to alter lever pressing (Fig. 4, top panel, black bars).

LY379268 also reduced responding under the response maintenance FR1 schedule of food delivery $[\mathrm{F}(3,17)=27.7, \mathrm{p}<0.01]$. The dose of $5.6 \mathrm{mg} / \mathrm{kg}$ produced a significant $(\mathrm{p}<0.01)$ reduction in responding as compared to vehicle while the lower doses of 1.0 and $3.0 \mathrm{mg} / \mathrm{kg}$ had no significant effect (Fig. 4, top panel, checkered bars).

Effect of the $\mathbf{C B}_{1}$ Receptor Antagonist Rimonabant on Reinstatement of FoodMaintained Responding: Rimonabant $(10.0 \mathrm{mg} / \mathrm{kg})$ significantly $(\mathrm{p}<0.01)$ reduced 
reinstated responding $[\mathrm{F}(1,14)=4.73, \mathrm{p}<0.05]$ (Fig. 4, bottom panel, black bars). Rimonabant failed to produce any effect on the maintenance of food-maintained responding under the FR1 schedule of response maintenance $[F(1,14)=0.74, p>0.05]$ (Fig. 4, bottom panel, checkered bars). 


\section{DISCUSSION}

Commonalities in behaviors, controlling variables, and biological substrates exist across drug- and non-drug reinforcers that initiate and maintain addictions (c.f., Chamberlain et al., 2016; Chen et al., 2017; Rogers, 2017; Volkow et al., 2012, 2017). For example, presentation of either morphine- or food-associated stimuli increased expression of NGFI-B in the medial and lateral portions of the prefrontal cortex (Kelley et al., 2005). Building upon the idea of reinforcer homology, we created a relatively rapid and non-surgical method for evaluating drugs for their potential to treat relapse in addiction states using food reinforcement. In contrast to the many weeks generally used in reinstatement models, we present data on a new method that generates assay results in 8 days.

We first showed that reinstatement of behavior could be induced by a host of stimuli. All experimental conditions investigated produced reinstatement of responding that was significantly greater than extinction response levels. These included stimuli associated with the reinforcer of food delivery, the reinforcer itself, and the stressor of foot shock. Thus, stimuli known to induce reinstatement of drug-taking (Shaham et al., 2003) were effective in reinstating food-seeking behavior in the current model as well.

A start to the pharmacological validation of the model was also presented here. Drugs used for treatment of addiction craving in patients, naltrexone and rimonabant (see Introduction for references) were studied. Rimonabant selectivity reduced relapse to food-seeking behavior, whereas naltrexone did not. The lack of activity of naltrexone in this model might point to the lack of firm data on the potential use of naltrexone in reducing hunger for food and food craving. However, the comparative data on naltrexone in non-food-based relapse models is also not extensive and there are reports of lack of efficacy (c.f., Comer et al., 1993). Naltrexone is also not markedly effective alone in treating obesity (Narayanaswami and Dwoskin, 2017). In contrast, the efficacy of rimonabant is congruent with findings with food addictions as well as drug reinforcers (see Introduction). Further pharmacological validation of the current model with positive controls will require clinical efficacy of new agents and the firm establishment of efficacy of existing agents. This is a situation faced in the validation of all animal models as prefaced in the introduction.

Although drugs were shown here to attenuate relapse to food-seeking behaviors, the mechanisms by which they produced this effect is likely complex. For example, suppression of reinstatement could be generated by the induction of a state distinct from the non-drug food-taking state (state-dependency, e.g.,, Self and Choi, 2004). Arguments against state-dependency can be made (e.g., not all drugs suppressed reinstatement and FR1 responding was differentially affected by some drugs that reinstated responses). Multiple other mechanisms should also be scrutinized and experimentally tested. For example, drug effects on appetite might have influenced the reinstatement process. If 
that were the case, one would predict $d$-amphetamine and rimonabant, appetite suppressants, to decrease responding. However, increases in FR1 responding were reported with $d$-amphetamine and no effect was shown with rimonabant on FR1 responding. Although, it is known that drug effects on behavior do not always follow motivational theory (c.f., Kelleher and Morse, 1968; Witkin and Katz, 1990), it is important to scrutinize all possibilities when exploring new models.

In addition to rimonabant, two glutamatergic mechanisms that have been implicated in relapse (see Introduction for references), $\mathrm{mGlu}_{2 / 3}$ receptors and $\mathrm{mGlu}_{5}$ receptors were also investigated. These receptor mechanisms were explored using specific pharmacological ligands, LY379268 ( $\mathrm{mGlu}_{2 / 3}$ receptor agonist) MPEP ( $\mathrm{mGlu}_{5}$ receptor antagonist), and MTEP ( $\mathrm{mGlu}_{5}$ receptor antagonist). All three compounds selectively reduced reinstatement of food-seeking behavior. Some drugs not typically associated with relapse prevention were also studied. Clozapine, $d$-amphetamine, chlordiazepoxide, ABT-431, and citalopram were not effective in reducing relapse to food-seeking. Other compounds that have shown efficacy in attenuating reinstatement of behavior by drugs, such as memantine (Popik et al., 2006), were not studied here but could be employed in future studies for model validation. Additional studies are also needed with drugs with efficacy in patients (e.g., lorcaserin) (Narayanaswami and Dwoskin, 2017) and those that are not.

In addition to pharmacological specificity, we also began to explore the behavioral specificity of drug action. Theoretically, a drug that reduces reinstatement should do so without affecting ancillary behaviors. For example, if a drug reduced reinstatement of food-seeking but also decreased the ability to normally find and eat food, this would not be a valuable medicine. We found that for the drugs that reduced reinstatement in the present study (rimonabant, MTEP, MPEP, and LY379268), there was a separation in doses that decreased reinstated behavior and doses that decreased normal ongoing food-maintained behavior. Work will need to be done to further address the question of behavioral specificity. In the present study, the baseline maintenance behavior (FR1) was not identical in all ways to the reinstated behavior - different amounts of behavior generated and different schedules of food delivery.

The data on the glutamatergic ligands also adds to the experimental literature suggesting value for glutamatergic mechanisms as potential anti-addiction agents based upon neuroanatomical (Childress et al., 1999; Garavan et al., 2000; Grant et al., 1996; Kilts et al., 2001; Maas et al., 1998; Wang et al., 1999; Wexler et al., 2001; Tzschentke, 2001; Tzschentke and Schmidt, 2000) and functional (Cornish and Kalivas, 2000; McFarland and Kalivas, 2001; Meil and See, 1997; Richard, 2019) outcomes as well as data from reinstatement models with $\mathrm{mGlu}_{5}$ receptor antagonists and $\mathrm{mGlu}_{2 / 3}$ receptor agonists (see Introduction). We have previously shown that an $\mathrm{mGlu}_{5}$ receptor antagonist reduces relapse to food-seeking in wild-type mice but not in Glu $_{5}-/$ - mice (Eiler et al., 
2011). The utility of this mechanism in food craving might now be added to the list of potential therapeutic applications.

We conclude that the 8-day assay method presented here might provide a method for the rapid detection of new pharmacological approaches to the treatment of relapse associated with addictions. Although the model uses food as a reinforcer, the pharmacological data at present point to the possibility of generality to addictive behaviors as a whole. The evidence suggests this possibility since drugs (with the possible exception of naltrexone) that were active in preclinical relapse models using drugs as reinforcers were active in the food-based model studied here. It should be noted that unlike chronic addiction phenomenon for drugs (e.g., Staples et al., 2015) or food (Butler and Eckel, 2018; Lee and Dixon, 2017) that generally develop over long periods of time and involve neural remodeling, the present model might not recapitulate these neuroplasticity dynamics.

It is well-known that despite commonalities in controlling variables and neurobiological substrates across reinforcers as discussed here, different reinforcers also control behavior in distinct ways (c.f., Banks, 2017; Martin-Fardon and Weiss, 2017). Thus, the likelihood of this model being able to provide precise prediction of drug effects across all reinforcer domains should also not be counted on. Nonetheless, the ability to generalize to multiple relapsing phenomenon is important: there are many stimuli that guide addictive behaviors (drugs, gambling, shopping, internet use, etc.) and all have been shown to have deleterious impacts on lives. As with all preclinical models, ultimate validation must come from data on the efficacy of compounds in patients. The medical need for improved medicines in this domain is high from both a health (e.g., Brady et al., 2016) and economic (e.g., Winkler et al., 2017) perspective. 


\section{REFERENCES}

Alt A, Weiss B, Ogden AM, Li X, Gleason SD, Calligaro DO, Bleakman D, Witkin JM. 2006 In vitro and in vivo studies in rats with LY293558 suggest AMPA/kainate receptor blockade as a novel potential mechanism for the therapeutic treatment of anxiety disorders. Psychopharmacology (Berl). 185(2):240-7.

Anggadiredja K, Sakimura K, Hiranita T, Yamamoto T. 2004 Naltrexone attenuates cuebut not drug-induced methamphetamine seeking: a possible mechanism for the dissociation of primary and secondary reward. Brain Res. 1021(2), 272-276.

Bäckström P, Bachteler D, Koch S, Hyytiä P, Spanagel R. 2004 mGluR5 antagonist MPEP reduces ethanol-seeking and relapse behavior. Neuropsychopharmacology 29(5), 921-928.

Balschun D, Wetzel W. 2002 Inhibition of mGluR5 blocks hippocampal LTP in vivo and spatial learning in rats. Pharmacol Biochem Behav. 73(2):375-80.

Banks ML. Utility of preclinical drug versus food choice procedures to evaluate candidate medications for methamphetamine use disorder. Ann N Y Acad Sci. 2017 Apr;1394(1):92-105.

Baptista MA, Martin-Fardon R, Weiss F. 2004 Preferential effects of the metabotropic glutamate 2/3 receptor agonist LY379268 on conditioned reinstatement versus primary reinforcement: comparison between cocaine and a potent conventional reinforcer. J Neurosci. 24(20), 4723-4727.

Barrett JE. 1987 Nonpharmacological factors determining the behavioral effects of drugs. In Meltzer HY (ed.), Psychopharmacology: The Third Generation of Progress, New York, Raven Press, 1493-1501.

Berthoud HR. 2004 Mind versus metabolism in the control of food intake and energy balance. Physiol Behav 81:781-93.

Bespalov AY, Dravolina OA, Sukhanov I, Zakharova E, Blokhina E, Zvartau E, Danysz W, van Heeke G, Markou A. 2005 Metabotropic glutamate receptor (mGluR5) antagonist MPEP attenuated cue- and schedule-induced reinstatement of nicotine self-administration behavior in rats. Neuropharmacology 49 Suppl 1, 167-178.

Blaha CD, Yang CR, Floresco SB, Barr AM, Phillips AG. 1997 Stimulation of the ventral subiculum of the hippocampus evokes glutamate receptor-mediated changes in dopamine efflux in the rat nucleus accumbens. Eur J Neurosci 9: 902911.

Brady KT, McCauley JL, Back SE. 2016 Prescription opioid misuse, abuse, and treatment in the United States: An update. Am J Psychiatry. 173(1), 18-26. 
Brody AL, Mandelkern MA, London ED, Childress AR, Lee GS, Bota RG, Ho ML, Saxena S, Baxter LR Jr, Madsen D, Jarvik ME. 2002 Brain metabolic changes during cigarette craving. Arch Gen Psychiatry 59:1162-72.

Butler MJ, Eckel LA. Eating as a motivated behavior: modulatory effect of high fat diets on energy homeostasis, reward processing and neuroinflammation. Integr Zool. 2018 Nov;13(6):673686.

Brown SA, Vik PW, Patterson TL, Grant I, Schuckit MA. 1995 Stress, vulnerability and adult alcohol relapse. J Stud Alcohol 56:538-545

Chamberlain SR, Lochner C, Stein DJ, Goudriaan AE, van Holst RJ, Zohar J, Grant JE. 2016 Behavioural addiction-A rising tide? Eur Neuropsychopharmacol. 26(5), 841-855.

Chen M, Sun Y, Lu L, Shi J. 2017 Similarities and Differences in Neurobiology. Adv Exp Med Biol. 1010, 45-58.

Chiamulera C, Epping-Jordan MP, Zocchi A, Marcon C, Cottiny C, Tacconi S, Corsi M, Orzi F, Conquet F. 2001 Reinforcing and locomotor stimulant effects of cocaine are absent in mGluR5 null mutant mice. Nat Neurosci. 4(9):873-4.

Childress AR, Mozley PD, McElgin W, Fitzgerald J, Reivich M, O’Brien CP. 1999 Limbic activation during cue-induced cocaine craving. Am J Psychiatry 156:1118

Ciccocioppo R, Lin D, Martin-Fardon R, Weiss F. 2003 Reinstatement of ethanolseeking behavior by drug cues following single versus multiple ethanol intoxication in the rat: effects of naltrexone. Psychopharmacology (Berl) 168(1-2), 208-215.

Cohen C, Perrault G, Griebel G, Soubrié P. 2005 Nicotine-associated cues maintain nicotine-seeking behavior in rats several weeks after nicotine withdrawal: reversal by the cannabinoid (CB1) receptor antagonist, rimonabant (SR141716). Neuropsychopharmacology. 30(1), 145-155.

Comer SD, Lac ST, Curtis LK, Carroll ME. 1993 Effects of buprenorphine and naltrexone on reinstatement of cocaine-reinforced responding in rats. J Pharmacol Exp Ther. 267(3), 1470-1477.

Cornish JL, Kalivas PW. 2000 Glutamate transmission in the nucleus accumbens mediates relapse in cocaine addiction. J Neurosci 20: RC89 (1-5). 
Cowen MS, Djouma E, Lawrence AJ. 2005 The metabotropic glutamate 5 receptor antagonist 3-[(2-methyl-1,3-thiazol-4-yl)ethynyl]-pyridine reduces ethanol selfadministration in multiple strains of alcohol-preferring rats and regulates olfactory glutamatergic systems. J Pharmacol Exp Ther. 315(2):590-600.

Cowen MS, Krstew E, Lawrence AJ. 2007 Assessing appetitive and consummatory phases of ethanol self-administration in C57BL/6J mice under operant conditions: regulation by mGlu5 receptor antagonism. Psychopharmacology (Berl). 190(1):21-9.

Davis WM, Smith SG. 1976 Role of conditioned reinforcers in the initiation, maintenance and extinction of drug-seeking behavior. Pavlovian J Biol Sci 11:222-236.

De Vries TJ, Shaham Y, Homberg JR, Crombag H, Schuurman K, Dieben J, Vanderschuren LJ, Schoffelmeer AN. 2001 A cannabinoid mechanism in relapse to cocaine seeking. Nat Med. 7(10), 1151-1154

Eiler WJ 2nd, Baez M, Yu J, Witkin JM. 2011 mGlu5 receptor deletion reduces relapse to food-seeking and prevents the anti-relapse effects of mGlu5 receptor blockade in mice. Life Sci. 89(23-24), 862-867.

Floresco SB, Yang CR, Phillips AG, Blaha CD. 1998 Basolateral amygdala stimulation evokes glutamate receptor-dependent dopamine efflux in the nucleus accumbens of the anesthetised rat. Eur J Neurosci 10: 1241-1251.

Garavan H, Pankiewicz J, Bloom A, Cho JK, Sperry L, Ross TJ, Salmeron BJ, Risinger R, Kelley D, Stein EA. 2000 Cue-induced cocaine craving: neuroanatomical specificity for drug users and drug stimuli. Am J Psychiatry 157: 1789-1798.

Grant S, London ED, Newlin DB, Villemagne VL, Liu X, Contoreggi C, Phillips RL, Kimes AS, Margolin A. 1996 Activation of memory circuits during cue-elicited cocaine craving. Proc Natl Acad Sci USA 93: 12040-12045.

Homayoun H, Stefani MR, Adams BW, Tamagan GD, Moghaddam B. 2004 Functional Interaction Between NMDA and mGlu5 Receptors: Effects on Working Memory, Instrumental Learning, Motor Behaviors, and Dopamine Release.

Neuropsychopharmacology. 29(7):1259-69.

Hunt WA, Barnett LW, Branch LG. 1971 Relapse rates in addiction programs. J Clin Psychol 27:455-456. 
Iso Y, Grajkowska E, Wroblewski JT, Davis J, Goeders NE, Johnson KM, Sanker S, Roth BL, Tueckmantel W, Kozikowski AP. 2006 Synthesis and structure-activity relationships of 3-[(2-methyl-1,3-thiazol-4-yl)ethynyl]pyridine analogues as potent, noncompetitive metabotropic glutamate receptor subtype 5 antagonists; search for cocaine medications. J Med Chem. 49(3):1080-100.

Jaffe JH, Cascell NG, Kumor KM, Sherer MA. 1989 Cocaine induced cocaine craving. Psychopharmacology 97:59-64

Justinova Z, Le Foll B, Redhi GH, Markou A, Goldberg SR. 2016 Differential effects of the metabotropic glutamate $2 / 3$ receptor agonist LY379268 on nicotine versus cocaine self-administration and relapse in squirrel monkeys. Psychopharmacology (Berl). 233(10), 1791-1800.

Kelleher RT, Morse WH. Determinants of the specificity of behavioral effects of drugs. Ergeb Physiol. 1968;60:1-56

Kelley AE, Schiltz CA, Landry CF. 2005 Neural systems recruited by drug- and foodrelated cues: studies of gene activation in corticolimbic regions. Physiol Behav. 86(1-2):11-4.

Kenny PJ, Boutrel B, Gasparini F, Koob GF, Markou A. 2005 Metabotropic glutamate 5 receptor blockade may attenuate cocaine self-administration by decreasing brain reward function in rats. Psychopharmacology (Berl). 179(1):247-54.

Kenny PJ, Markou A. 2004 The ups and downs of addiction: role of metabotropic glutamate receptors. Trends Pharmacol Sci. 2004 May;25(5):265-72.

Kilts CD, Schweitzer JB, Quinn CK, Gross RE, Faber TL, Muhammad F, Ely TD, Hoffman JM, Drexler KP. 2001 Neural activity related to drug craving in cocaine addiction. Arch Gen Psychiatry 58: 334-341.

Kim JH, Perry C, Luikinga S, Zbukvic I, Brown RM, Lawrence AJ. 2015 Extinction of a cocaine-taking context that protects against drug-primed reinstatement is dependent on the metabotropic glutamate 5 receptor. Addict Biol. 20(3), 482-489.

Kirkham T. 2008 Endocannabinoids and the neurochemistry of gluttony. J Neuroendocrinol. 20(9), 1099-1100.

Knackstedt LA, Schwendt M. 2016 mGlu5 receptors and relapse to cocaine-seeking: The role of receptor rrafficking in postrelapse extinction learning deficits. Neural Plast. 2016, 9312508. 
Koch M. 2017 Cannabinoid receptor signaling in central regulation of feeding behavior: A mini-review. Front Neurosci. 11, 293.

Lee PC, Dixon JB. Food for Thought: Reward Mechanisms and Hedonic Overeating in Obesity. Curr Obes Rep. 2017 Dec;6(4):353-361

Lee B, Platt DM, Rowlett JK, Adewale AS, Spealman RD. 2005 Attenuation of behavioral effects of cocaine by the metabotropic glutamate receptor 5 antagonist 2-Methyl-6-(phenylethynyl)-pyridine in squirrel monkeys: comparison with dizocilpine. J Pharmacol Exp Ther. 312(3):1232-40.

Liu X, Weiss F. 2002 Additive effect of stress and drug cues on reinstatement of ethanol seeking: exacerbation by history of dependence and role of concurrent activation of corticotropin-releasing factor and opioid mechanisms. J Neurosci. 22(18), :7856-7861.

Lu YM, Jia Z, Janus C, Henderson JT, Gerlai R, Wojtowicz JM, Roder JC. 1997 Mice lacking metabotropic glutamate receptor 5 show impaired learning and reduced CA1 long-term potentiation (LTP) but normal CA3 LTP. J Neurosci. 17(13):5196-205.

Ludwig AM, Wikler A, Stark LH. 1974 The first drink. Psychobiological aspects of craving. Arch Gen Psychiatry 30:539-547.

Maas LC, Lukas SE, Kaufman MJ, Weiss RD, Daniels SL, Rogers VW, Kukes TJ, Renshaw PF. 1998 Functional magnetic resonance imaging of human brain activation during cue-induced cocaine craving. Am J Psychiatry 155: 124-126.

Martin-Fardon R, Weiss F. Perseveration of craving: effects of stimuli conditioned to drugs of abuse versus conventional reinforcers differing in demand. Addict Biol. 2017 Jul;22(4):923-932.

McFarland K, Kalivas PW. 2001 The circuitry mediating cocaine induced reinstatement of drug-seeking behavior. J Neurosci 21: 8655-8663.

Meil WM, See RE. 1997 Lesions of the basolateral amygdala abolish the ability of drugassociated cues to reinstate responding during withdrawal from self-administered cocaine. Behav Brain Res 87: 139-148.

Narayanaswami V, Dwoskin LP. Obesity: Current and potential pharmacotherapeutics and targets. Pharmacol Ther. 2017 Feb;170:116-147.

O’Brien CP, Childress AR, Mclellan TA, Ehrman R. 1992 Classical conditioning in drug dependent humans. Ann NY Acad Sci 654:400-415.

O'Brien CP. 1997 A range of research-based pharmacotherapies for addiction. Science 278:66-70. 
Paterson NE, Semenova S, Gasparini F, Markou A. 2003 The mGluR5 antagonist MPEP decreased nicotine self-administration in rats and mice. Psychopharmacology (Berl) 167(3):257-64.

Piomelli D. 2001 Cannabinoid activity curtails cocaine craving. Nat Med. 7(10), 10991100.

Pomierny-Chamiolo L, Miszkiel J, Frankowska M, Bystrowska B, Filip M. 2017a Cocaine self-administration, extinction training and drug-induced relapse change metabotropic glutamate mGlu5 receptors expression: Evidence from radioligand binding and immunohistochemistry assays. Brain Res. 1655, 66-76.

Pomierny-Chamiolo L, Miszkiel J, Frankowska M, Mizera J, Filip M. 2017b Neuroadaptive changes in metabotropic glutamate mGlu2/3R expression during different phases of cocaine addiction in rats. Pharmacol Rep. 69(5), 1073-1081.

Popik P, Wrobel M, Bisaga A. Reinstatement of morphine-conditioned reward is blocked by memantine. Neuropsychopharmacology. 2006 Jan;31(1):160-70.

Richard JM Metabotropic glutamate receptor 5 signaling and appetitive Pavlovian behavior: implications for the treatment of addiction. Neuropsychopharmacology. 2019 Apr 9. doi: 10.1038/s41386-019-0375-y. [Epub ahead of print]

Rogers PJ 2017 Food and drug addictions: Similarities and differences. Pharmacol Biochem Behav. 153, 182-190.

Rubio MA, Gargallo M, Isabel Millán A, Moreno B. 2007 Drugs in the treatment of obesity: sibutramine, orlistat and rimonabant. Public Health Nutr. 10(10A), 1200-1205.

Schindler CW, Redhi GH, Vemuri K, Makriyannis A, Le Foll B, Bergman J, Goldberg SR, Justinova Z. 2016 Blockade of nicotine and cannabinoid reinforcement and relapse by a cannabinoid CB1-receptor neutral antagonist AM4113 and inverse agonist rimonabant in squirrel monkeys. Neuropsychopharmacology. 41(9), 2283-2293.

Schroeder JP, Overstreet DH, Hodge CW. 2005 The mGluR5 antagonist MPEP decreases operant ethanol self-administration during maintenance and after repeated alcohol deprivations in alcohol-preferring $(\mathrm{P})$ rats. Psychopharmacology (Berl). 179(1):262-70.

Self DW, Choi KH. Extinction-induced neuroplasticity attenuates stress-induced cocaine seeking: a state-dependent learning hypothesis. Stress. 2004 Sep;7(3):145-55. 
Shaham Y, Shalev U, Lu L, de Wit H, Stewart J. 2003 The reinstatement model of drug relapse: history, methodology and major findings. Psychopharmacology (Berl). 168(1-2), 3-20.

Simonyi A, Schachtman TR, Christoffersen GR. 2005 The role of metabotropic glutamate receptor 5 in learning and memory processes. Drug News Perspect. 18(6):353-61.

Sinha R. 2001 How does stress increase risk of drug abuse and relapse. Psychopharmacology 158:343-359

Staples MC, Kim A, Mandyam CD. Dendritic remodeling of hippocampal neurons is associated with altered NMDA receptor expression in alcohol dependent rats. Mol Cell Neurosci. 2015 Mar;65:153-62.

Stretch R, Gerber GJ, Wood SM. 1971 Factors affecting behavior maintained by response-contingent intravenous infusions of amphetamine in squirrel monkeys. Can J Physiol Pharmacol 49:581-589.

Tessari M, Pilla M, Andreoli M, Hutcheson DM, Heidbreder CA. 2004 Antagonism at metabotropic glutamate 5 receptors inhibits nicotine- and cocaine-taking behaviours and prevents nicotine-triggered relapse to nicotine-seeking. Eur $\mathbf{J}$ Pharmacol. 499(1-2):121-33.

Tzschentke TM. 2001 Pharmacology and behavioural pharmacology of the mesocortical dopamine system. Prog Neurobiol 63: 241-320.

Tzschentke TM, Schmidt WJ. 2000 Functional relationship among medial prefrontal cortex, nucleus accumbens, and ventral tegmental area in locomotion and reward. Crit Rev Neurobiol 14: 131-142.

Volkow ND, Wang GJ, Fowler JS, Tomasi D, Baler R. 2012 Food and drug reward: overlapping circuits in human obesity and addiction. Curr Top Behav Neurosci. 11, 1-24.

Volkow ND, Wise RA, Baler R. The dopamine motive system: implications for drug and food addiction. Nat Rev Neurosci. 18(12), 741-752.

Walsh SL, Haberny KA, Bigelow GE. 2000 Modulation of intravenous cocaine effects by chronic oral cocaine in humans. Psychopharmacology 150:361-373 
Wang GJ, Volkow ND, Fowler JS, Cervany P, Hitzemann RJ, Pappas NR, Wong CT, Felder C. 1999 Regional brain metabolic activation during craving elicited by recall of previous drug experiences. Life Sci 64: 775-784.

Ward SJ, Rosenberg M, Dykstra LA, Walker EA. 2009 The CB1 antagonist rimonabant (SR141716) blocks cue-induced reinstatement of cocaine seeking and other context and extinction phenomena predictive of relapse. Drug Alcohol Depend. 105(3), 248-255.

Wasserman DA, Weinstein MG, Havassy BE, Hall SM. 1998 Factors associated with lapses to heroin use during methadone maintenance. Drug Alcohol Depend 52:183-192

Wexler BE, Gottschalk CH, Fulbright RK, Prohovnik I, Lacadie CM, Rounsaville BJ, Gore JC. 2001 Functional magnetic resonance imaging of cocaine craving. Am J Psychiatry 158: 86-95.

Wikler A. 1973 Dynamics of drug dependence. Implications of a conditioning theory for research and treatment. Arch Gen Psychiatry. 28(5), 611-616.

Wikler A, Pescor FT. 1967 Classical conditioning of a morphine abstinence phenomenon, reinforcement of opioid-drinking behavior and "relapse" in morphine-addicted rats. Psychopharmacologia. 10(3), 255-284.

Willner P. The validity of animal models of depression. Psychopharmacology (Berl). 1984;83(1):116.

Winkler P, Bejdová M, Csémy L, Weissová A. 2017 Social Costs of Gambling in the Czech Republic 2012. J Gambl Stud. 33(4), 1293-1310.

Witkin JM, Katz JL 1990 Analysis of behavioral effects of drugs. Drug Devel. Res. 20, 389-409. 


\section{TABLE LEGEND}

Table 1. Summary of the effects of various drugs on reinstatement and maintenance of food-maintained responding.

\begin{tabular}{|c|c|c|c|c|}
\hline Mechanism & Compound & Dose (mg/kg) & Reinstatement & FR1 \\
\hline Antipsychotic/ $/ \mathrm{D}_{2}$ receptor antagonist & chlorpromazine & 5.6 & NS & NS \\
\hline Anxiolytic/GABA ${ }_{\mathrm{A}}$ receptor potentiator & chlordiazepoxide & 20 & NS & NS \\
\hline $\mathrm{D}_{1}$ receptor agonist & ABT-431 & 1 & $\mathrm{NS}$ & Not tested \\
\hline Indirect dopamine agonist & $d$-amphetamine & 3 & NS & 4 \\
\hline $\mathrm{CB}_{1}$ receptor antagonist & rimonabant & 10 & $\downarrow$ & NS \\
\hline \multirow[t]{3}{*}{$\mathrm{mGlu}_{2 / 3}$ receptor agonist } & LY379268 & 1 & NS & NS \\
\hline & & 3 & $\downarrow$ & NS \\
\hline & & 5.6 & $\downarrow$ & $\downarrow$ \\
\hline \multirow[t]{3}{*}{$\mathrm{mGlu}_{5}$ receptor antagonist } & MPEP & 3 & NS & NS \\
\hline & & 5.6 & $\downarrow$ & NS \\
\hline & & 10 & $\downarrow$ & NS \\
\hline \multirow[t]{3}{*}{ mGlu $_{5}$ receptor antagonist } & MTEP & 3 & NS & NS \\
\hline & +2 & 5.6 & $\downarrow$ & $\mathrm{NS}$ \\
\hline & $\bar{s}$ & 10 & $\downarrow$ & NS \\
\hline Opioid receptor antagonist & naltrexone & 10 & NS & NS \\
\hline $\begin{array}{l}\text { Antidepressant /Selective serotonin } \\
\text { reuptake inhibitor }\end{array}$ & citalopram & 3 & NS & Not tested \\
\hline
\end{tabular}

Arrows indicate significant reductions or increases in responding when compared to vehicle. NS: not significantly different than vehicle control values.

Results of ANOVA for rimonabant, LY379268, MPEP, and MTEP are provided in the results section. One-way ANOVA results for the other compounds in this table are as follows:

Chlorpromazine: Reinstatement $[\mathrm{F}(1,16)=0.64, \mathrm{p}>0.05]$; FR1 $[\mathrm{F}(1,14)=0.79, \mathrm{p}>$ 0.05]

Chlordiazepoxide Reinstatement $[\mathrm{F}(1,16)=0.48, \mathrm{p}>0.05]$; FR1 $[\mathrm{F}(1,14)=0.62, \mathrm{p}>$ 0.05]

ABT431: Reinstatement $[\mathrm{F}(1,14)=0.37, \mathrm{p}>0.05]$.

d-Amphetamine: Reinstatement $[\mathrm{F}(1,14)=0.45, \mathrm{p}>0.05]$; FR1 $[\mathrm{F}(1,16)=4.2, \mathrm{p}<$ 0.05]

Naltrexone: Reinstatement $[\mathrm{F}(1,14)=0.29, \mathrm{p}>0.05]$; FR1 $[\mathrm{F}(1,14)=0.41, \mathrm{p}>0.05]$.

Citalopram: Reinstatement $[\mathrm{F}(1,16)=0.61, \mathrm{p}>0.05]$. 


\section{FIGURE LEGENDS}

Figure 1. Effect of various stimuli on the ability to reinstate responding after extinction of food maintained responding. Each bar represents the mean ( \pm SEM) of 5-9 rats/group. $* p<0.05$ compared to data of comparable group on the last day of extinction (control: C1-C6).

Figure 2. Acquisition, extinction, and reinstatement of food-maintained responding in three separate group of rats. Each point represents the mean ( \pm SEM) of 5-9 rats/group. On day 8 , responses produced in separate groups of rats either food alone (filled circle), food + food-associated stimuli (unfilled circle), or food-associated stimuli alone (triangle). \# $\mathrm{p}<0.05$ compared to data of comparable group on the last day of response acquisition. ${ }^{*} \mathrm{p}<0.05$ compared to the last day of extinction.

Figure 3. Top Panel: Effect of MTEP $(3.0-10.0 \mathrm{mg} / \mathrm{kg})$ on the reinstatement of foodmaintained responding (black bars) or on the maintenance of responding under the FR1 schedule (checkered bars). Bottom Panel: Effect of MPEP $(3.0-10.0 \mathrm{mg} / \mathrm{kg})$ on the reinstatement of food-maintained responding (black bars) or on the maintenance of responding under the FR1 schedule (checkered bars). All data are shown as mean ( \pm SEM) of 5-9 rats/group. * ${ }^{*}<0.05$ compared to vehicle with Dunnett's post-hoc.

Figure 4. Top Panel: Effect of LY379268 $(1.0-5.6 \mathrm{mg} / \mathrm{kg}$ on the reinstatement of foodmaintained responding (black bars) or on the maintenance of responding under the FR1 schedule (checkered bars). Bottom Panel: Effect of rimonabant $(10.0 \mathrm{mg} / \mathrm{kg}$ ) on the reinstatement of food-maintained responding (black bars) or on the maintenance of responding under the FR1 schedule (checkered bars). All data are shown as mean ( \pm SEM) of 5-9 rats/group. $\mathrm{p}<0.05 * * \mathrm{p} \leq 0.01$ compared to vehicle with Dunnett's posthoc. 
Figure 1.

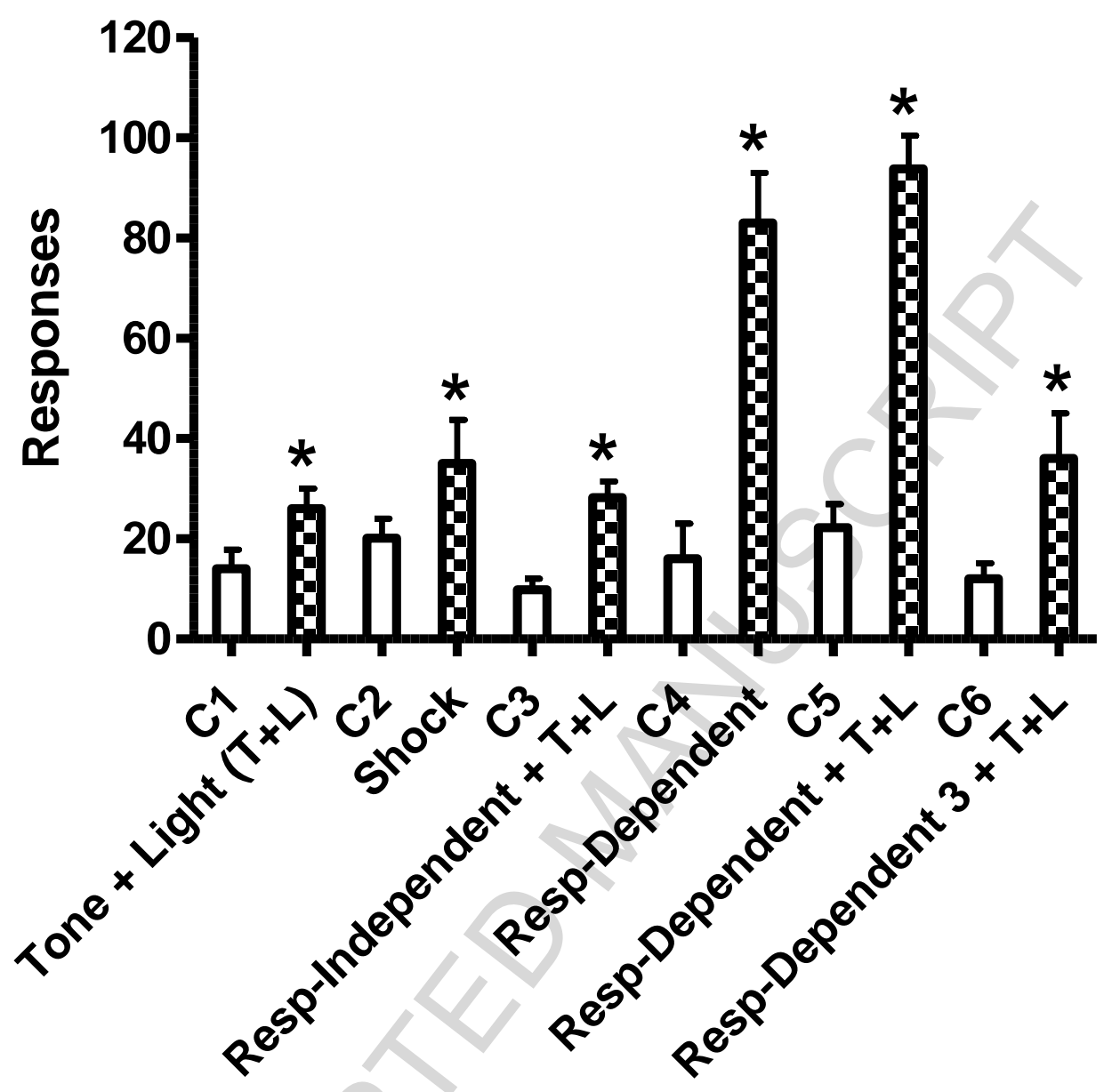




\section{Figure 2.}

Acquisition, Extinction, and Reinstatement of Extinguised Behavior Maintained by Food Presenation

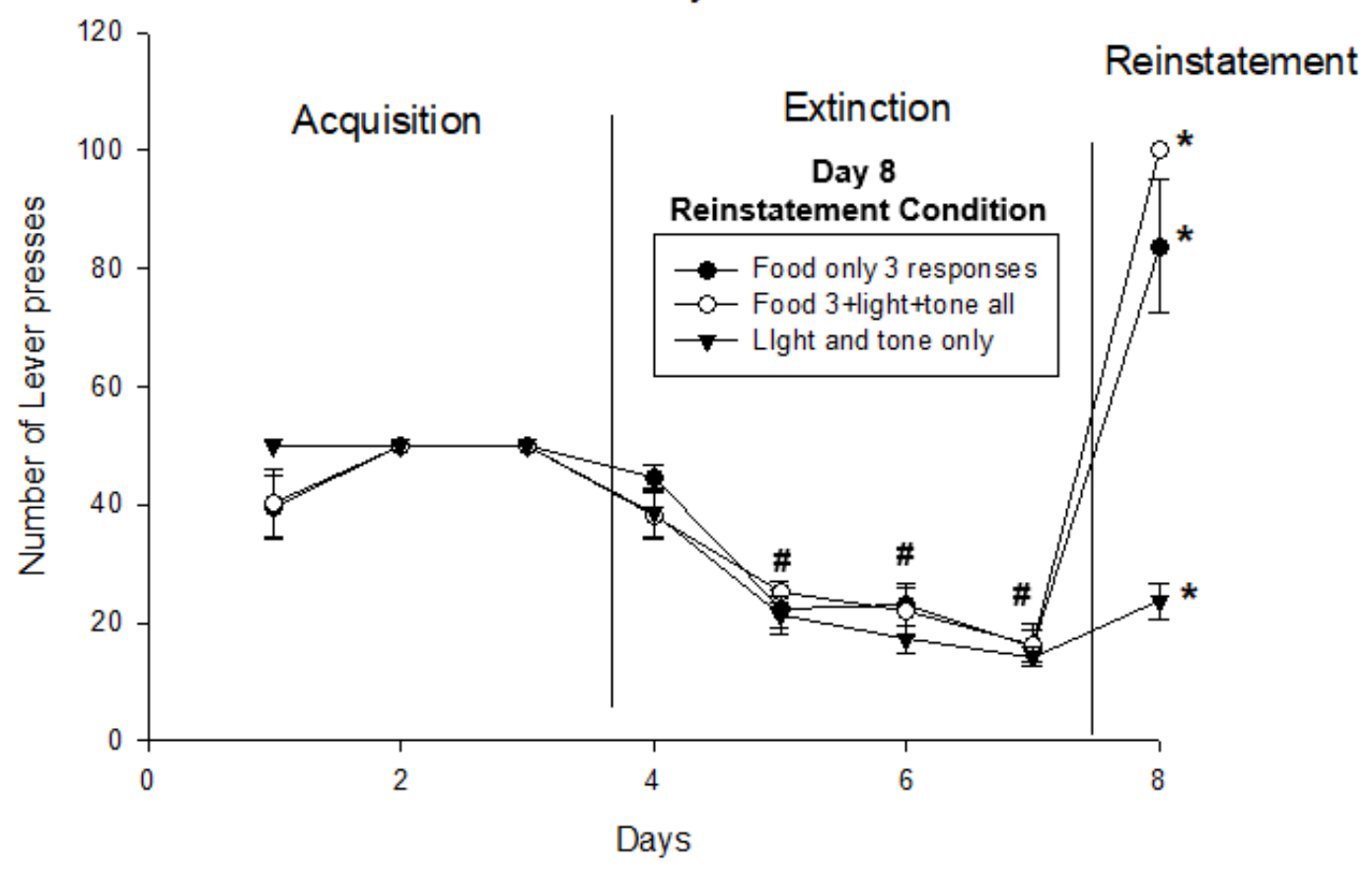


Figure 3.
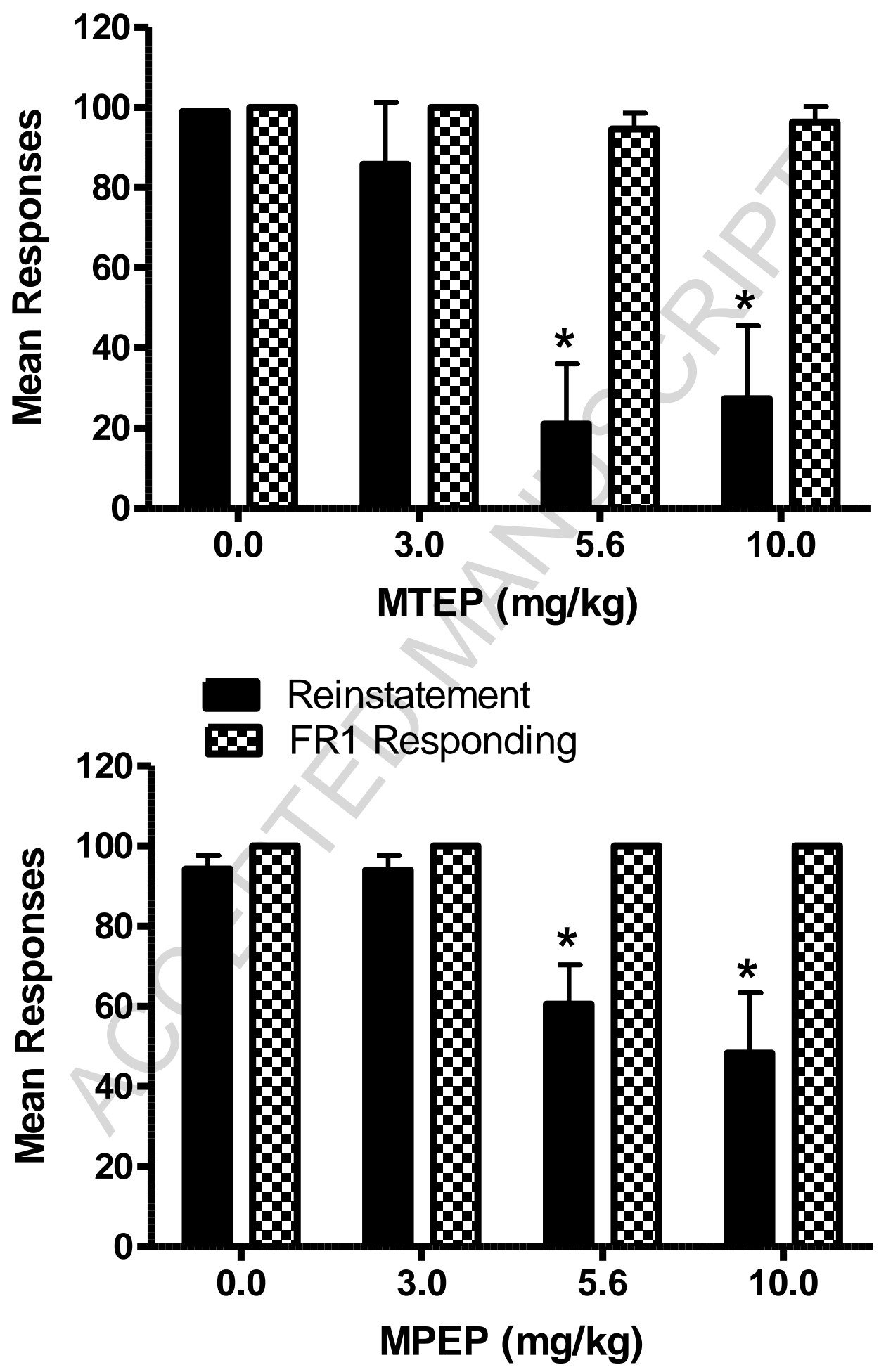
Figure 4

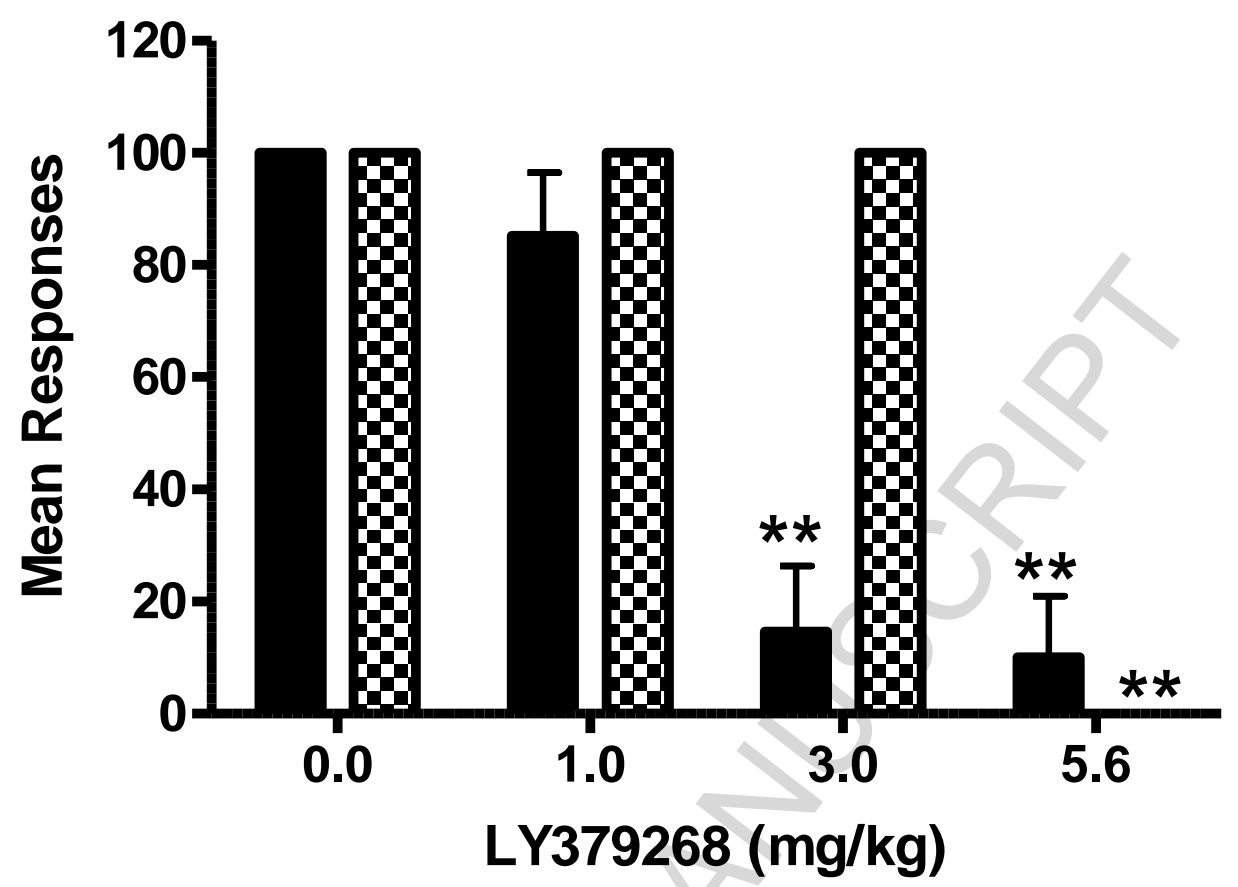

Reinstatement

Ex FR1 Responding

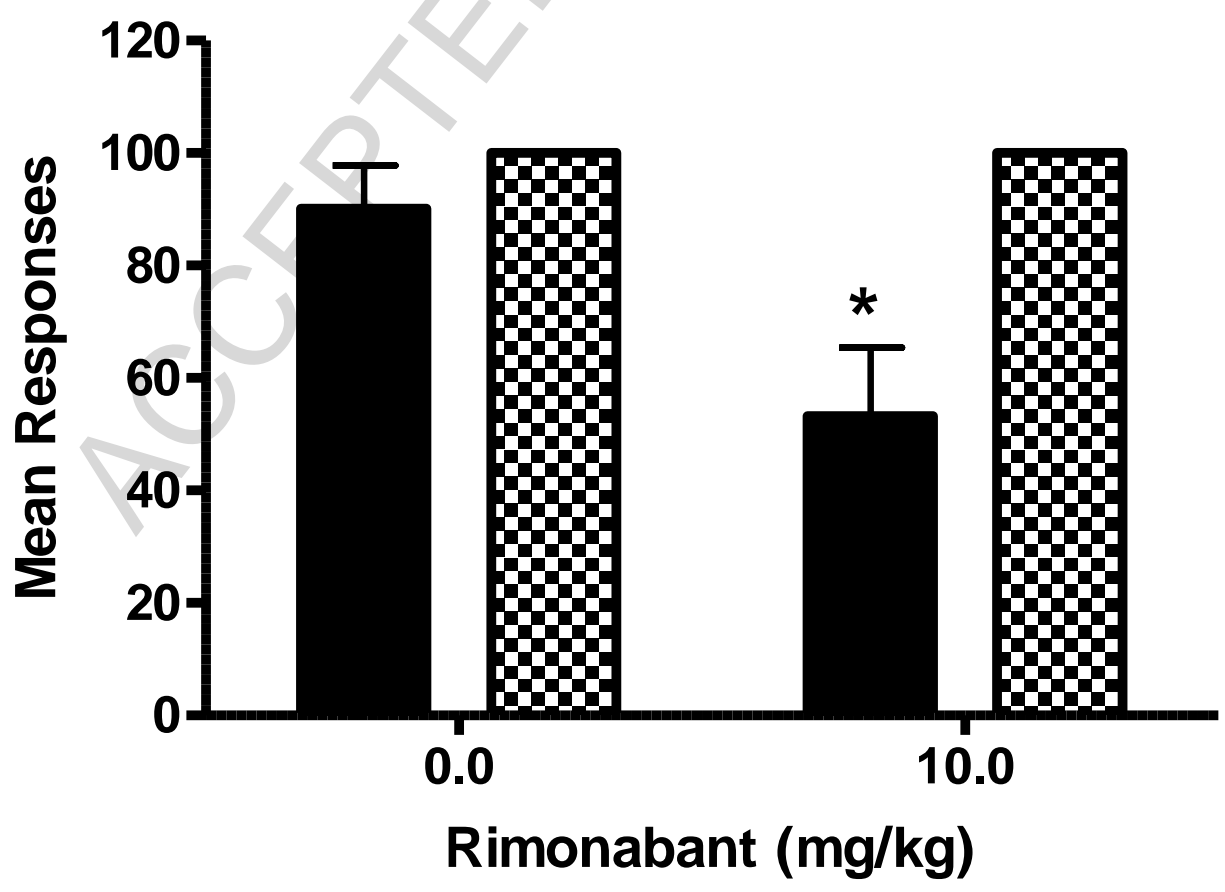




\section{A medium throughput rodent model of relapse from addiction with behavioral and pharmacological specificity}

\section{Highlights}

An 8-day rat model of reinstatement is presented using food reinforcement

Rimonabant, LY379268, MTEP, and MPEP suppressed reinstatement

Reinstatment was suppressed at doses without effect on ongoing behavior

Clozapine, $d$-amphetamine, chlordiazepoxide, ABT-431, naltrexone and citalopram were inactive

The model might be useful for screening compounds for addiction-associated relapse 